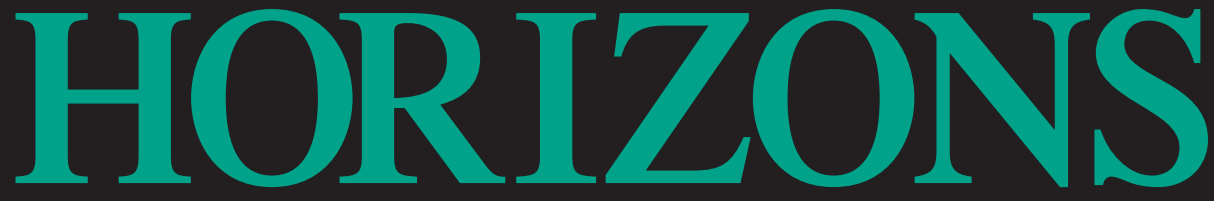

Volume 37

Spring 2010

Number 1

\title{
ARTICLES
}

Kimberly Baker, Augustine's Doctrine of the Totus Christus: Reflecting on the Church as Sacrament of Unity

Francis J. Caponi, OSA, Pale Analogies and Dead Metaphors:

Some Recent Trends in Religious Language

Jürgen Mettepenningen, Yves Congar and the "Monster" of Nouvelle Théologie

Kari-Shane Davis Zimmerman, Hooking Up: Sex, Theology, and Today's

"Unhooked" Dating Practices

\section{EDITORIAL ESSAY}

Bradford Hinze, A Decade of Disciplining Theologians

\section{REVIEW SYMPOSIUM}

Bryan N. Massingale, Racial Justice and the Catholic Church

Four Perspectives: Laurie Cassidy, Charles E. Curran, James H. Evans, Jr., Jana Bennett

Author's Response: Bryan N. Massingale

Plus Reviews of 35 Books

\section{THE JOURNAL OF THE COLLEGE THEOLOGY SOCIETY}




\title{
HORIZONS
}

\section{The Journal of the College Theology Society}

\author{
Published at Villanova University
}

Volume 37

Spring 2010

Number 1

\section{ARTICLES}

Augustine's Doctrine of the Totus Christus:

Reflecting on the Church as Sacrament of Unity Kimberly Baker

Pale Analogies and Dead Metaphors: Some Recent

Trends in Religious Language.....

Yves Congar and the "Monster" of

Nouvelle Théologie

Hooking Up: Sex, Theology, and Today's

"Unhooked" Dating Practices Kari-Shane Davis Zimmerman

EDITORIAL ESSAY

A Decade of Disciplining Theologians

Bradford Hinze

\section{REVIEW SYMPOSIUM}

Bryan N. Massingale, Racial Justice and the Catholic Church

Four Perspectives Laurie Cassidy

Author's Response Bryan N. Massingale

\section{BOOK REVIEWS}

Mary L. Coloe, Dwelling in the Household of God:

Johannine Ecclesiology and Spirituality .... Richard Gaillardetz

Todd A. Salzman and Michael Lawler, The Sexual Person:

Toward a Renewed Catholic Anthropology Stephen J. Casey

Bruno Forte, The Portal of Beauty: Toward a Theology

of Aesthetics.....

Daniel B. Gallagher

Terrence W. Tilley, The Disciples' Jesus: Christology as

Reconciling Practice

Elena G. Procario-Foley

Philip J. Rossi, The Social Authority of Reason: Kant's Critique,

Radical Evil, and the Destiny of Mankind

Joseph M. Incandela

Joseph Martos, The Sacraments: An Interdisciplinary

and Interactive Study

Timothy Brunk

John Ranieri, Disturbing Revelation: Leo Strauss,

Eric Voegelin, and the Bible William Thompson-Uberuaga

Joerg Rieger, Christ and Empire: From Paul to

Postcolonial Times

Michael Kirwin, Girard and Theology

David Cornick, Letting God Be God:

The Reformed Tradition
Alexis James Doval 151 . William P. O’Brien, SJ 152

Brother Jeffrey Gros, FSC 
Norman L. Geisler and Joshua Betancourt, Is Rome the True Church?

A Consideration of the Roman Catholic Claim. William M. Shea

Ben Witherington, III, The Problem with Evangelical Theology:

Testing the Foundations of Calvinism, Dispensationalism

and Wesleyanism William M. Shea

Charles E. Curran, Catholic Moral Theology in the

United States: A History James J. Walter

Thomas A. Nairn, ed., The Consistent Ethic of Life:

Assessing Its Reception and Relevance. Edward Vacek, SJ

William C. Mattison, III, Introducing Moral Theology:

True Happiness and the Virtues Timothy E. O'Connell

Robert Obach, The Catholic Church on Marital Intercourse: From

Saint Paul to Pope John Paul II Kari-Shane Davis Zimmerman 160

Ursula King, The Search for Spirituality: Our Global

Quest for a Spiritual Life. Eileen Flanagan

Kathleen McAlpin, Ministry That Transforms: A Contemplative

Process of Theological Reflection Marie Conn

Susan Conroy and David J. Dwyer, trans., The Plays of St. Thérèse of Lisieux;

Marc Foley, OCD, The Context of Holiness: Psychological and Spiritual

Reflections on the Life of St. Thérèse of Lisieux Joann Wolski Conn

Daniel G. Groody, Globalization, Spirituality, and Justice:

Navigating the Path to Peace. Elizabeth Hinson-Hasty 165

Abbot Christopher Jamison, Finding Happiness: Monastic Steps for

Fulfilling Life; Aquinata Böckmann, Around the Monastic Table:

Growing in Mutual Service and Love Mary Forman, OSB 166

Rose Mary Dougherty, SSND, Discernment: A Path to

Spiritual Awakening Ellen Stratton 168

Louis Dupré, Religion and the Rise of

Modern Culture Joseph A. Bracken, SJ 168

Richard Wayne Willis, Sr., Martin Luther King Jr. and the Image of God. Thomas Massaro, SJ 169

Gerald O'Collins and Michael Hayes, eds., The Legacy of John Paul II John V. Kruse 170

Leonard Swidler, Making the Church Our Own: How We Can

Reform the Catholic Church from the Ground Up

M. Shawn Copeland, The Subversive Power of Love:

The Vision of Henriette Delille. Bradford Hinze

Ian Ker and Terrence Merrigan, eds., The Cambridge Companion

to John Henry Newman Walter E. Conn 174

Rembert G. Weakland, OSB, A Pilgrim in a Pilgrim Church:

Memoirs of a Catholic Archbishop David Cozzens

Colin E. Gunton, The Barth Lectures Paul D. Molnar

John Keenan, Grounding Our Faith in a Pluralist

World-with a little help from Nagarjuna Paul F. Knitter

Gregory Baum, The Theology of Tariq Ramadan:

A Catholic Perspective.... Jeannine-Hill Fletcher 180

Catherine Cornille, The Im-Possibility of

Interreligious Dialogue Peter Feldmeier

Copyright @ 2010 College Theology Society

Printed in the United States of America 


\section{HORIZONS}

\section{The Journal of the College Theology Society}

Horizons, The Journal of the College Theology Society is published biannually in Spring and Fall at Villanova University, Villanova, PA 19085.

Yearly subscription: individual \$16.00, institutional $\$ 40.00$. Send remittance, payable to College Theology Society, P.O. Box 465, Hanover, PA 17331. Changes of address should also be sent to this address. Horizons is automatically received through membership in the College Theology Society.

Manuscripts, editorial and business correspondence, book reviews, advertising copy, and orders for single issues (individual \$8.00, institutional $\$ 20.00$ ) should be addressed to The Editor, Horizons, St. Mary’s Hall, Villanova University, Villanova,PA 19085. Telephone:(610) 519-7302.E-mail:HORIZONS@ VILLANOVA.EDU

In submitting manuscripts, please send four clear copies. Author's name should appear only on an unpaginated cover sheet, with address and essay's title. No other identifying reference to author should appear on the manuscript. All references to author's work in text or notes should be in the third person. Essay's title should appear at top of first page of text. Notes should be placed on separate sheets at end. Full double spacing should be used throughout, including indented quotations and notes. Top, bottom, and right-hand margins should be at least one inch; left-hand margins at least one-and-a-half. Manuscripts should be accompanied by an abstract of one hundred fifty words or less and an author vita of one hundred words or less. Authors should state that the manuscript will not be submitted to another journal until Horizons' evaluation is completed. Manuscripts will be returned if postage is supplied.

Articles appearing in Horizons are abstracted and indexed in: The Catholic Periodical and Literature Index; Guide to Social Science and Religion in Periodical Literature; Index to Religious Periodical Literature; New Testament Abstracts; Religious and Theological Abstracts; and Social Science Citation Index. Articles are indexed in Religion Index One: Periodicals; book reviews indexed in Index to Book Reviews in Religion. Horizons is available in microform from Bell \& Howell, 300 North Zeeb Road, P.O. Box 1346, Ann Arbor, MI 48106-1346. It is also available on line in full text to ATLAS subscribers.

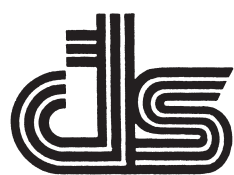

\section{COLLEGE THEOLOGY SOCIETY}

The College Theology Society is a professional organization of college and university professors of religion in the United States and Canada.

The purpose of the College Theology Society is to improve the quality of the teaching of religion: by stimulating and sharing scholarly research; by developing programs of theology and religious studies which meet student needs and interests; and by exploring, evaluating, and encouraging effective ways of teaching which are interdisciplinary and ecumenical.

Annual membership dues in the Society are $\$ 50.00$ (Full Professional or Associate), $\$ 50.00$ (Joint Professional for husband and wife), and \$25.00 (Graduate Student). Membership in the Society includes a subscription to Horizons. Contact Daniel T. Michaels, KEYPOPPY Christian Resources, 1726 West Cape Rock Drive, Cape Girardeau, MO 63701. Telephone: (573) 651-4199. E-mail: dmichaels@keypoppy.com 


\section{EDITOR}

Anthony J. Godzieba

Villanova University

\section{ASSISTANT EDITOR}

Elena G. Procario-Foley

Iona College

\section{ASSOCIATE EDITORS}

Lisa Sowle Cahill

Boston College

Denise Lardner Carmody

Santa Clara University

Bernard Cooke

College of the Holy Cross (Emeritus)

Lawrence S. Cunningham

University of Notre Dame

Charles E. Curran

Southern Methodist University

Margaret A. Farley

Yale Divinity School

Elisabeth Schüssler Fiorenza

Harvard Divinity School

Francis Schüssler Fiorenza

Harvard Divinity School
Mary Ann Hinsdale Boston College

Elizabeth A. Johnson

Fordham University

Paul F. Knitter

Union Theological Seminary, NY

Pheme Perkins

Boston College

Sandra M. Schneiders, IHM Jesuit School of Theology at Berkeley

William M. Shea

College of the Holy Cross

Gerard S. Sloyan

Temple University (Emeritus)

David Tracy

University of Chicago

\section{BOOK REVIEW EDITORS}

Joann Wolski Conn

Neumann University
Eileen Flanagan

Neumann University

BUSINESS EDITOR

Gerald S. Vigna

Alvernia College

EDITORIAL ASSISTANT

Irene C. Noble

\section{EDITOR EMERITUS}

Walter E. Conn

Villanova University 


\section{From the Editor}

Since our Fall 2009 issue appeared, the Roman Catholic Church has been rocked by two episodes that have created a crisis of conscience for many. The first was an event specific to the United States, the vociferous debates over the health care reform bill in Congress that eventually pitted the American bishops over against the Catholic health care community. The comments from partisans on both sides ranged from thoughtful argument and commentary to wild accusations and high-schoolish name-calling. (I'm probably not alone in detecting, in the aftermath of these controversies, a whiff of Donatism in the air.) The second episode, still unfolding, is the scandal affecting the universal Church: the explosion of reports of physical and sexual abuse of children-in Germany, then throughout Europe, eventually including South America-and the subsequent revelations of cover-ups and the shuffling of priest-personnel on the part of various dioceses. These horrific reports and the outrage provoked by them have had consequences reaching all the way into the Vatican and have led to the resignations of bishops for either covering up crimes (as in Ireland) or being abusers themselves (a German bishop and a Belgian bishop). In what has become a revolting sidebar, the revelations concerning Fr. Marcial Maciel and his Legionaries of Christ (recently reported by Jason Berry in the National Catholic Reporter) have served only to reinforce the fear that the rot has reached into the very heart of the institution.

To say that these events have left an already fragile Church even more wounded, even fractured, would be an understatement. To pose two questions out of a host of important ones raised by these events: how do the current perceptions of Catholicism affect our students and our teaching? How should professors of theology and religious studies at Catholic institutions cope with this, both personally and professionally? I raise these questions in the wake of one posed on the America Magazine blog by Tom Beaudoin, professor of religion and religious education at Fordham University: "In the face of what is being revealed about the Catholicism that has been so much my atmosphere, how can I justify my intellectual work?" ("The Expiration Date of This Catholicism: Being a Theologian in an Abusive Church," http://www.americamagazine.org/ blog/entry.cfm?blog_id=2\&entry_id=2685 [accessed 29 April 2010]). In a future issue, we hope to explore further the connection between our "professing" in the classroom and the current fractured and contentious ecclesial context in which we perform it. But at the very least we cannot ignore that context, nor the perceptions that act as a screen through which our religious claims are viewed by students and colleagues alike.

The articles in this issue address (serendipitously, not by plan!) the current context from diverse angles. Augustine's doctrine of the Church as totus Christus (Kimberly Baker), twentieth-century Catholic theology's struggle with modernity (Jürgen Mettepenningen), the challenge of young adults' changing views of intimate relationships and a theological anthropology that can speak to these views (Kari-Shane Davis Zimmerman), and the problem of the "panmetaphoricism" and reference in religious language (Francis Caponi), our book review symposium on Bryan Massingale's important new book Racial Justice and the Catholic Church-these are all ways at getting at the issue of the plausibility of Christian thinking and speaking about God in a context where Catholicism is now more likely to be judged life-denying than life-affirming. And our editorial essay (Bradford Hinze) directly addresses one difficult aspect of the role of theologians today, the sometimes contentious relationship they have with the Roman magisterium. 